University of Nebraska - Lincoln

DigitalCommons@University of Nebraska - Lincoln

Transactions of the Nebraska Academy of

Sciences and Affiliated Societies

Nebraska Academy of Sciences

Fall 12-1-2021

\title{
Habitat associations and activity patterns of herpetofauna in the Central Platte River Valley, Nebraska, with notes on morphometric characteristics
}

\author{
Jenna M. Malzahn \\ Platte River Whooping Crane Maintenance Trust, jmalzahn@cranetrust.org \\ Andrew J. Caven \\ Platte River Whooping Crane Maintenance Trust, acaven@cranetrust.org \\ Sean Warren \\ University of Nebraska - Lincoln, seanwarren1124@gmail.com \\ Bethany L. Ostrom \\ Platte River Whooping Crane Maintenance Trust, bostrom@cranetrust.org \\ Dennis M. Ferraro \\ University of Nebraska - Lincoln, dferraro1@unl.edu
}

Follow this and additional works at: https://digitalcommons.unl.edu/tnas

Part of the Biodiversity Commons

\begin{abstract}
Malzahn, Jenna M.; Caven, Andrew J.; Warren, Sean; Ostrom, Bethany L.; and Ferraro, Dennis M., "Habitat associations and activity patterns of herpetofauna in the Central Platte River Valley, Nebraska, with notes on morphometric characteristics" (2021). Transactions of the Nebraska Academy of Sciences and Affiliated Societies. 535.

https://digitalcommons.unl.edu/tnas/535
\end{abstract}

This Article is brought to you for free and open access by the Nebraska Academy of Sciences at DigitalCommons@University of Nebraska - Lincoln. It has been accepted for inclusion in Transactions of the Nebraska Academy of Sciences and Affiliated Societies by an authorized administrator of DigitalCommons@University of Nebraska - Lincoln. 


\title{
Habitat associations and activity patterns of herpetofauna in the Central Platte River Valley, Nebraska, with notes on morphometric characteristics
}

\author{
Jenna Malzahnn ${ }^{1}$, Andrew J. Caven ${ }^{1,}$, Sean Warren², Bethany Ostrom ${ }^{1}$, and Dennis Ferraro ${ }^{2}$ \\ 1 Platte River Whooping Crane Maintenance Trust, Inc., Wood River, NE 68883, USA. \\ 2 School of Natural Resources, University of Nebraska-Lincoln, Lincoln, NE 68583, USA. \\ * Corresponding author : acaven@cranetrust.org; (605)-252-8007
}

\begin{abstract}
The Central Platte River Valley (CPRV) is a unique and biologically important ecoregion, and several studies have conducted localized herpetofauna species inventories. However, there has been significantly less effort to quantify the habitat associations or activity patterns of these species. Habitat associations and activity patterns vary regionally and provide important information for ecosystem management. We deployed a total of 38 traps of 5 different types (pitfall, funnel, hoop, box, and coverboard) across 11 sites (7 terrestrial, 4 aquatic) for an 8-week period in June and July 2019. Our exploratory analyses used generalized linear models with a quasibinomial distribution to examine associations between herpetofauna abundance (captures per trap night) and habitat characteristics controlling for trap type. Habitat characteristics assessed included distance to nearest woodland, distance to nearest standing water, vegetation species richness, soil texture, and vegetative cover in addition to others. We also evaluated activity patterns weekly across the study period. The two most abundant species demonstrated divergent distributional patterns, Northern Prairie Skinks were only absent from two of the driest terrestrial sites, while the Six-lined Racerunners were locally abundant at just three sites with significant bare ground and sandy soils. We documented a Cope's Gray Treefrog at a site with little woody cover in which the species had not been previously observed, suggesting it may be increasingly widespread regionally. We also detected relatively widespread juvenile anuran dispersal at multiple terrestrial sites a considerable distance from standing water. Our results provide a preliminary examination of habitat associations and summer activity patterns for herpetofauna in the CPRV that can be used to inform conservation efforts and further studies of this system.
\end{abstract}

Keywords: Central Platte River Valley, herpetofauna, Northern Prairie Skink, Six-lined Racerunner, Cope's Gray Treefrog, habitat associations, activity patterns, dispersal, Lowland Tallgrass Prairie

doi $10.32873 /$ unl.dc.tnas. 41.8

\section{Introduction}

The Central Platte River Valley (CPRV) is designated a biologically unique landscape by the Nebraska Game and Parks Commission, and contains two areas designated by the National Audubon Society as globally important bird areas including the Crane Trust's Wild Rose Ranch/Mormon Island complex as well as the Audubon Society's Rowe Sanctuary (Schneider et al. 2011, Poague 2019). The CPRV is designated as critical habitat for the endangered Whooping Crane (Grus americana; USFWS 1978) and supports a diversity of vascular plants and wildlife, including several species of herpetofauna (or regional analogs) that Whooping Cranes are known to consume (Allen 1952, Ballinger 1980, Geluso et al. 2013,
Geluso and Harner 2013a, 2013b, Zimorski et al 2013, Dinets 2016).

The CPRV is unique as a result of fluctuating groundwater levels that create a mosaic of wetlands with varying hydroregimes and subirrigated grasslands that result from wide seasonal variation in the Platte River's flows and stochastic rainfall events (Currier 1982, 1995, Goldowitz and Whiles 1999, Henszey et al. 2004, Caven et al. 2019a). Several studies have inventoried the herpetofauna of the Crane Trust's Wild Rose Ranch and Mormon Island properties as they represent the largest tract $(\sim 6,000$ acres) of lowland tallgrass prairie and wet meadow habitat remaining in the CPRV (Ballinger 1980, Geluso and Harner 2013, Caven and Malzahn 2019). A recent study by Geluso and Harner (2013a) documented 15 herpetofauna 
Table 1. Habitat data for 7 terrestrial sampling sites surveyed from 5 June to 30 July 2019 in the Central Platte River Valley including distance to woodland (meters; Dist. Wood), distance to surface water as of 30 July (meters; Dist. H2O), percent vegetative cover between 0.5 and $2 \mathrm{~m}$ height (Veg. $<2.0 \mathrm{~m}$ ), percent ground cover as bare ground (BG), soil type (Soil) broadly classified as sandy or having a significant loam component, the grass and forb with the highest percent cover (Dominant Grass, Forb), the percent of total vegetative cover made up by exotic species (Exo.), the wetland indicator scale (WIS) for each site, and the total number of plant species (Spp.) detected via point-line intercept surveys.

\begin{tabular}{lrrrrllllll} 
Site & $\begin{array}{l}\text { Dist. } \\
\text { Wood }\end{array}$ & $\begin{array}{r}\text { Dist. } \\
\mathrm{H}_{2} \mathrm{O}\end{array}$ & $\begin{array}{r}\text { Veg. } \\
\text { <2.0m }\end{array}$ & BG & Soil & Dominant Grass & Dominant Forb & Exo. & WIS & Spp. \\
\hline Fort Kearny Ridge (FKR) & 45.4 & 107.0 & 80 & 10 & Sand & Calamovilfa longifolia & Ambrosia psilostachya & 27.8 & 4.20 & 7 \\
Fort Kearny Prairie (FKP) & 238.5 & 11.0 & 70 & 50 & Sand & Setaria faberi & Lotus purshianus & 52.9 & 4.43 & 12 \\
Martin's Mead. Ridge (MMR) & 532.0 & 37.5 & 80 & 100 & Sand & Eragrostis trichodes & Callirhoe involucrata & 16.7 & 3.67 & 5 \\
Martin's Mead. Prairie (MMP) & 731.0 & 49.5 & 100 & 100 & Loam & Andropogon gerardii & Asclepias verticillata & 20.0 & 4.00 & 7 \\
Ruge Prairie (RP) & 13.0 & 62.0 & 100 & 60 & Loam & Bromus inermis & Aster ericoides & 50.0 & 3.44 & 10 \\
North Brown Ridge (NBR) & 225.0 & 15.4 & 50 & 50 & Sand & Bromus inermis & Ambrosia psilostachya & 40.0 & 3.75 & 9 \\
SE Mormon Woodland (SMW) & 0.0 & 70.0 & 100 & 0 & Loam & Bromus inermis & Toxicodendron radicans & 50.0 & 4.67 & 4 \\
\hline
\end{tabular}

species in the area including four anuran, three turtle, two lizard, and six snake species. Caven and Malzahn (2019) documented an additional two anuran species during vocalization surveys in 2018 and 2019 (Spea bombifrons and Hyla chrysoscelis), resulting in an estimated 17 herpetofauna species present at these properties (H. chrysoscelis also documented by McLean et al. 2015). However, there is limited regionally specific information regarding the habitat associations of these species. A number of studies have described the characteristics of sites where particular species of conservation interest have been located, but there have been few efforts to quantify those features (McLean et al. 2015, Caven et al. 2017a, Tye et al. 2017, Wiese and Caven 2017).

Habitat associations can vary regionally for herpetofauna species and understanding them is essential to effective conservation planning and ecosystem management (Welsh et al. 1995, Brooks et al. 2004, Jones and Dorr 2004). We recorded habitat data (vegetation, soil type, etc.) along with species capture rates at 11 sites to further clarify herpetofauna habitat associations in the CPRV. We also recorded activity patterns and morphometric data to improve our understanding of species' natural histories regionally.

\section{Study Sites}

The CPRV contains a variety of habitats across a relatively narrow elevational gradient that are structured and sustained by fluctuating groundwater levels tied to the Platte River including shallow marsh, wet meadows, riparian woodlands, lowland tallgrass prairies, and upland sandy ridges (Currier 1982, 1995, Kantrud et al. 1989, Henszey et al. 2004, Whiles and Goldowitz 2005, Kaul et al. 2012). The Platte River provides subirrigated moisture to vascular plant communities allowing the region to support a more mesic flora than would exist as a result of rainfall alone (Currier 1995, Currier and Henszey 1996, Henszey et al. 2004, Kaul et al. 2012, Tiner 2016).

Our study sites were located between Grand Island and Kearney, Nebraska, with the easternmost site on Mormon Island in Hall County (N 40 48.515 , W 98 22.912, $575 \mathrm{~m}$ elev.) and the westernmost site on rangeland in Kearney County (N 40³6.175, W 9900.498, $653 \mathrm{~m}$ elev.). Nine of the sites were on land owned by the Crane Trust, a non-profit organization, with the goal of preserving habitat for Whooping Cranes, Sandhill Cranes, and other migratory birds (VanDerwalker 1982). To mimic historic natural disturbance patterns, Crane Trust property is managed with rotational grazing and prescribed fire (Fuhlendorf et al. 2009). Two additional study sites were located on private property. Our terrestrial study sites were mainly in lowland tallgrass prairie and upland sandy ridge habitats (Kantrud et al. 1989, Currier 1995, Kaul et al. 2012), while our aquatic study sites were composed of excavated pond (see Pauley et al. 2018) and permanent slough (see Meyer and Whiles 2008) wetlands (Table 1, Appendix 1). 


\section{Methods and Materials}

\section{Sampling Design}

We deployed a total of 38 traps across 11 sites for an 8-week period from 5 June to 30 July 2019 (Appendix 1). All sites were located outside of actively grazed pastures; however, four sites were located in areas burned within two years of the study and another site was recently hayed (Martin's Meadows Pond, burned 2019; Martin's Meadows Prairie, burned 2019; North Brown Slough, burned 2018; North Brown Ridge, burned 2018; Ruge Prairie, hayed 2019; Appendix 1). Following the recommendations of Wilson and Gibbons (2010), a variety of trapping methods were used to capture a wide range of herpetofauna. The trapping techniques employed are useful for determining species presence and abundance as well as relative abundance (Mengak and Guynn 1987, Corn 1994, Todd et al. 2007, Wilson and Gibbons 2010). We deployed a total of 7 drift fences paired with 2 pitfall traps each, 14 cover boards $\left(1 \mathrm{~m}^{2}\right)$, and two funnel traps ( $~ 1 \mathrm{~m}$ length and $\sim 12 \mathrm{~cm}$ diameter) across seven terrestrial sites, targeted toward capturing Squamata and Anura species. Pitfall traps were placed nearboth ends of each drift fence. We also deployed four hoop net traps ( $1 \mathrm{~m}$ diameter), targeted toward capturing Testudines species, and four box traps $(\sim 81 \times 46 \times 23 \mathrm{~cm})$, targeted toward capturing Ambystoma species. We attempted to keep trapping effort relatively equal between sites while allowing for targeted efforts to capture particular taxa, therefore our analyses consider both trap type and site.

\section{Herpetofauna Sampling}

We installed a trapping array at each of 7 terrestrial sites (Table 1, Appendix 1). These arrays consisted of a linear $25 \mathrm{~m}$ drift fence, supported by wooden stakes, with two 5-gallon buckets fit into the ground about $0.3 \mathrm{~m}$ from each end of the array to serve as pitfall traps. A string was attached to the drift fence and hung into each bucket allowing small mammals, which are generally efficient climbers, to escape as they were not target species (Karraker 2001). In the event of a rainstorm or flooding, bucket lids were cut in half for easier placement on buckets to prevent water accumulation. Two to 3 cover boards were placed at 5 terrestrial sites in $5 \mathrm{~m}$ increments, starting at one end of the drift fence, while a single funnel trap was placed at 2 terrestrial sites along the center of the drift fence.
Hoop net traps (4) were installed at two aquatic sites (Appendix 1), with the trap placed halfway in the water. Metal rebar was used to secure the trap and to assure it remained open and accessible. Each trap was baited with sardines, through an attached PVC pipe. Box traps (4) were also installed at two aquatic sites (Appendix 1), with the trap placed halfway in the water. Plastic poles were used to secure the traps in place. The traps were checked almost every morning, to minimize time trapped during peak temperatures, from 4 June 2019 to 30 July 2019. Date, time, location, trap type, species, temperature, and relative humidity were documented for each capture. Species measurements recorded include snout-vent length (SVL) for anurans, lizards, and salamanders, tail length for lizards and salamanders, full body length for snakes, and carapace length for turtles. Minimum snout-vent length measurements for adults, provided by Ballinger et al. (2010), were used to determine relative age class (i.e. juvenile, adult) of captured species.

To summarize species phenological activity patterns we tallied captures across all sites by survey week, for each of the eight survey weeks completed between 4 June and 30 July, regarding species having 2 or more total captures. Capture rates were calculated as the sum of captures per trap type divided by the number of corresponding trap nights at each site, which allowed us to assess relative abundance controlling for trap type (Mengak and Guynn 1987, Todd et al. 2007). We also tallied herpetofauna species richness as well as cumulative capture rate at each terrestrial site (Mengak and Guynn 1987, Todd et al. 2007).

\section{Habitat Characteristics Sampling}

We measured 10 habitat variables in total for each terrestrial site (Table 1). Vegetation cover and community composition below 2 meters height were assessed as well as ground cover at each site using a point-line intercept method, where dominant vegetation was recorded at each meter along a $10 \mathrm{~m}$ transect within two height classes $(<0.5 \mathrm{~m}$ and $0.5<2.0 \mathrm{~m}$ ) (Symstad et al. 2008, Caven et al. 2017). Transects were situated $2 \mathrm{~m}$ away and parallel to drift fence arrays in order to sample undisturbed vegetation. All species detected were identified to at least the genus level (e.g. - Carex sp.). Soil type was determined at each site using soil map data provided by the USDANRCS (2019) and in-field soil texturing techniques (NSW DPI 2015). At each terrestrial sampling site we also measured distance to nearest woodland and surface water on 
30 July 2019 using a rangefinder (Nikon Laser 800 6x21 $6.0^{\circ}$, Tokyo, Japan). If the topography did not allow for the use of the rangefinder, we estimated the straight-line distance to both habitat features using a Global Positioning System unit (GPS 73, Garmin Ltd., Lenexa, KS).

We determined the dominant grass and forb species for each terrestrial site by tallying the frequency vascular plant species were detected across both height classes surveyed ( $<0.5 \mathrm{~m} \& 0.5<2 \mathrm{~m}, \mathrm{n}=20$ samples). We then calculated the vegetative cover per each height class and the frequency of bare ground detected as opposed to litter from ground cover samples. We tallied species richness per each site and calculated the percent of total vegetative cover comprised by exotic species as defined by the USDA-NCRS (2019). We also calculated a simple average of the wetland indicator statuses (WIS) of all plant species detected via the point-line intercept method at each site (Reed 1988, Lichvar et al. 2016, Tiner 2016). Each plant is assigned a status based on the frequency they occur in wetlands compared to non-wetlands within distinct ecoregions of the United States (e.g., "Great Plains"; Reed 1988, Lichvar et al. 2016). Obligate wetland $(\mathrm{OBL}=1)$ plants occur within a wetland $>99 \%$ of the time, facultative wetland $(\mathrm{FACW}=2)$ plants occur within a wetland $67-99 \%$ of the time, facultative $(F A C=3)$ plants are equally likely to occur in wetland (34-66\%) and non-wetland habitats, facultative upland $(\mathrm{FACU}=4)$ species are less likely to occur in wetlands $(1-33 \%)$, and obligate upland $(\mathrm{UPL}=5)$ species very rarely $(<1 \%)$ occur in wetlands. The mean WIS score provided us a general measure of how mesic or xeric each site was with a score of near 1 indicating a site dominated by obligate wetland plants, suggesting a relatively permanent wetland site, and a score of near 5 indicating an upland site which very rarely experiences any flooding (Reed 1988, Tiner 2016).

\section{Statistical Analyses}

To examine the associations between herpetofauna species captured and terrestrial habitat characteristics we used the "stats" package in the program $\mathrm{R}$ to run a series of generalized linear models with a quasibinomial distribution due to overdispersion of the dependent variables (i.e., individual species' and site's capture rates, range $=$ 0.0 - 0.29; R Core Team 2015). We used models including only 1 independent variable (a single habitat feature) and 1 control variable (trap type as a fixed factor) to evaluate habitat features in relation to capture rates for species with multiple captures $(n \geq 2)$. Independent variables were discrete as well as continuous. We took this approach because we only had a sample of 14 unique trap-site combinations (7 sites each with 2 trap types a piece) on which to evaluate habitat features (Vittinghoff and McCulloch 2007). To ensure that our models were not impacted by multicollinearity we conducted Pearson's correlations between all trap types and independent variables using the "Hmisc" package in the program R (Dormann et a. 2013, Harrel 2016, R Core Team 2015). Trap types had less than a $|0.5|$ correlation with all independent variables, indicating that our analysis was not likely influenced by multicollinearity (Dormann et a. 2013).

\section{Results}

We captured a total of 84 individuals of 11 species across 1,739 trap nights. This included a total of 23 Six-lined Racerunners (Aspidoscelis sexlineatus), 20 Northern Prairie Skinks (Plestiodon septentrionalis), 15 Woodhouse's Toads (Anaxyrus woodhousii), 13 Boreal Chorus Frogs (Pseudacris maculata), 4 American Bullfrogs (Lithobates catesbeianus), 2 Painted Turtles (Chrysemys picta), 2 Plains Leopard Frogs (Lithobates blairi), 2 Lined Snakes (Tropidoclonion lineatum), 1 Common Lesser Earless Lizard (Holbrookia maculata), 1 Cope's Gray Treefrog (Hyla chrysoscelis), and 1 Plains Gartersnake (Thamnophis radix). Notably, we did not capture any Western Tiger Salamanders (Ambystoma mavortium) despite targeted trapping efforts.

Total captures ranged from 0 at Southeast Mormon Woodland to 39 individuals at Martin's Meadows Ridge site. Herpetological species richness ranged from 0 (Southeast Mormon Woodland) to 4 species at both Martin's Meadows Prairie and Fort Kearny Prairie (Figure 1). Northern Prairie Skinks were the most widespread squamata being detected at 5 sites (Figure 1). Total capture rates (all species combined across all trap types) were highest at Martin's Meadows Ridge and Fort Kearny Prairie and equaled just over 0.15 captures per trap night (Appendix 1; Figure 1). The highest capture rate across species at an individual site in a single trap type was 0.29 captures per pitfall trap night at Martin's Meadows Ridge (Figure 1). This site also had the highest combined rate of capture ( 0.17 per trap night) across trap types (cover board and pitfall) as well as within a particular trap type (0.15, pitfall; Figure 1) for a single species (Six-lined Racerunner). Pitfall traps demonstrated the highest total capture rates across terrestrial survey sites $(x \pm s e=0.11 \pm 0.4)$ 


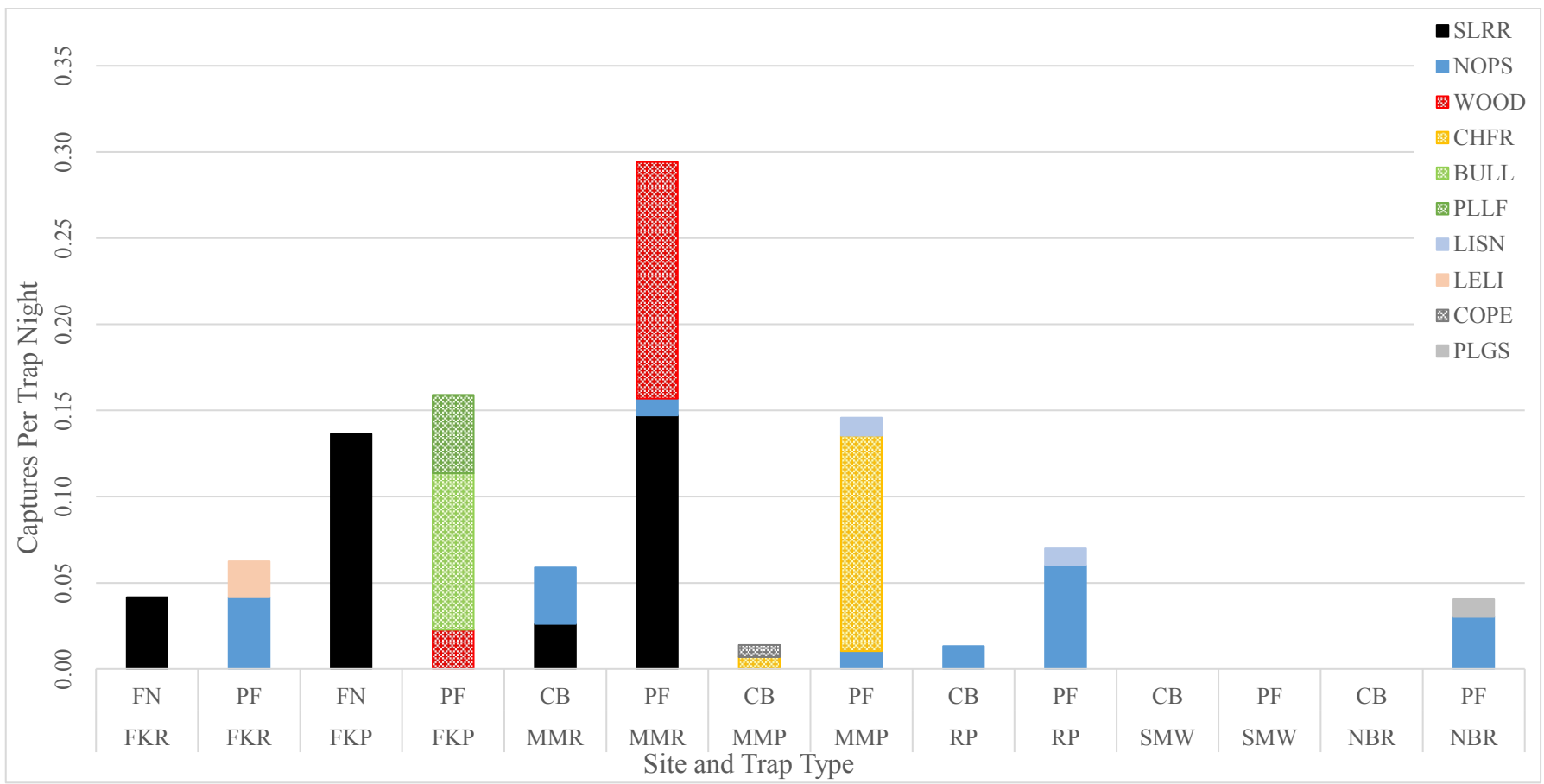

Figure 1. Herpetofauna captures per trap night for each trap type (FN= funnel; $P F=$ pitfall; $C B=$ cover board $)$ at each terrestrial site (FKR= Fort Kearny Ridge; FKP= Fort Kearny Prairie; MMR= Martin's Meadows Ridge; MMP= Martin's Meadows Prairie; RP= Ruge Prairie; NBR= North Brown Ridge; SMW= Southeast Mormon Woodland) for each species captured (BULL= American Bullfrog; CHFR= Boreal Chorus Frog; COPE= Cope's Gray Treefrog; LELI= C. Lesser Earless Lizard; LISN= Lined Snake; NOPS= Northern Prairie Skink; PLGS= Plains Gartersnake; PLLF= Plains Leopard Frog; SLRR= Six-lined Race Runner; WOOD= Woodhouse's Toad). Solid bars represent Squamata spp. and patterned bars represent Anura spp.

followed by funnel $(x \pm s e=0.09 \pm 0.05)$ and coverboard traps $(x \pm s e=0.02 \pm 0.02)$.

The Six-lined Racerunner demonstrated a positive relationship with bare ground $(B=0.056 \pm 0.020, p=0.018)$ as did the Woodhouse's Toad $(B=0.050 \pm 0.021, p=0.037)$. The Northern Prairie Skink only demonstrated a marginal negative association with WIS $(B=-2.085 \pm 0.989, p=0.062)$. Boreal Chorus Frogs displayed a strong positive relationship with distance to woodland, suggesting they are more abundant away from woodlands $(B=1.038 \mathrm{e}-01 \pm 1.621 \mathrm{e}-03$, $p<0.001)$. American Bullfrog capture rates decreased as distance to water increased $(B=-4.086 \pm 0.073, p<0.001)$ and capture rates increased with vegetation species richness $(B=10.190 \pm 0.173, p<0.001)$ as well as exotic species cover $(B=6.558 \pm 0.109, p<0.001)$. The Plains Leopard Frog demonstrated a strong negative relationship to distance to surface water $(B=-3.922 \pm 0.073, p<0.001)$, a positive relationship to vegetation species richness $(B=9.822 \pm 0.173$, $p<0.001$ ), and a positive relationship with exotic species cover $(B=6.311 \pm 0.109, p<0.001)$. The Lined Snake demonstrated no significant preferences modeled in this analysis but was most common at sites with a significant Big Bluestem (A. gerardii) vegetative component (Table 1).

We captured predominantly adult Squamata spp. and predominantly juvenile Anura spp. (Table 2). Six-lined Racerunner adults averaged $\left(x^{-} \pm S D\right) 58.8 \pm 4.8 \mathrm{~mm}$ snoutvent length and $103.6 \pm 19.2 \mathrm{~mm}$ tail length with juveniles averaging $43.8 \pm 5.5 \mathrm{~mm}$ snout-vent length and $68.7 \pm 7.19$ $\mathrm{mm}$ tail length. Adult Northern Prairie Skinks averaged $59.6+3.8 \mathrm{~mm}$ snout-vent length and $103.9+23.5 \mathrm{~mm}$ tail length with juveniles averaging $45.0 \pm 3.0 \mathrm{~mm}$ snout-vent length and $60.43 \pm 27.3 \mathrm{~mm}$ tail length. Juvenile Woodhouse's Toads averaged 25.1 $\pm 6.8 \mathrm{~mm}$ snout-vent length and juvenile Boreal Chorus Frogs averaged 14.8 $\pm 0.3 \mathrm{~mm}$ snout-vent length.

Most Boreal Chorus Frogs and Northern Prairie Skinks were captured earlier in the study period from weeks one to three, while captures of American Bullfrogs came exclusively during survey week seven near the end of the study (Figure 2). Six-lined Racerunners demonstrated a relatively quadratic capture rate, increasing in abundance across the first three weeks and 
Table 2. Herpetofauna morphometrics. Snout-vent length measurements for Anura and Squamata recorded from 5 June to 30 July 2019 at 7 terrestrial sampling sites in the Central Platte River Valley, Nebraska. "Adult" and "juvenile" determination was largely made using minimum SVL measurements for breeding age individuals in Nebraska (Ballinger et al. 2010) in the absence of other indicators. Sex was not recorded in this study. Not all individuals captured were measured therefore "N" may not equate to "total captures" in Figure 2.

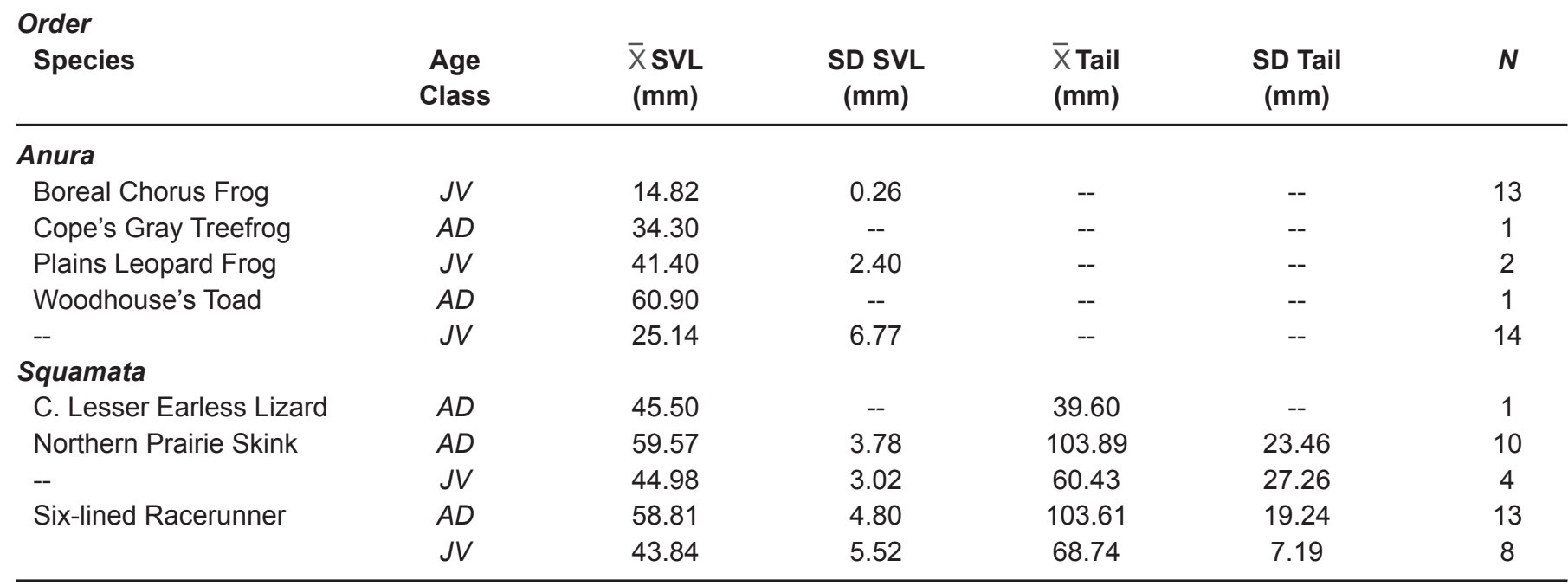

decreasing in abundance across the last three; however, capture rates of Six-lined Racerunners dropped significantly during weeks four and five (Figure 2). By contrast Woodhouse's Toads peaked in abundance during survey week five (Figure 2). Flooding occurred at some sites during the end of survey week five and through most of survey week six.

\section{Discussion}

\section{Six-lined Racerunner (Aspidoscelis sexlineatus)}

Habitat Associations - We captured Six-lined Racerunners at a sandy, mixed grass prairie (FKP) and two upland sandy ridge sites (FKR and MMR). Six-lined Racerunners are commonly found in open dry sandy areas with sparse vegetation in Nebraska (Ballinger et al. 1979, Jones et al. 1981, Lynch 1985, Ballinger et al. 2010, Geluso and Harner 2013a). Fogell (2010) found the most significant habitat feature to be low moisture. They are common in shortgrass prairie habitats and are generally absent from tallgrass prairies but can occupy more xeric microsites within these regions, which may explain their absence from the majority of our sites (Jones et al. 1981, Ballinger et al. 2010). Our finding that relative abundance was positively correlated with bare ground percentage corresponds to Fitch (1958), which found that Six-lined
Racerunners are common in overgrazed prairies and suggests the species is less restricted by sandy soil availability than by open area availability. Fitch (1958) did not find racerunners in any prairies unless there was extreme grazing or trampling.

Morphometrics - We captured thirteen adult Six-lined Racerunners averaging $58.81 \pm 4.8 \mathrm{~mm}$ for SVL and 103.61 $\pm 19.24 \mathrm{~mm}$ for tail length (Table 2 ). This species, in Nebraska, can reach total lengths of about $254 \mathrm{~mm}$ with adults averaging $63.7 \mathrm{~mm}$ in snout-vent length (Lynch 1985, Ballinger et al. 2010, Fogell 2010). We also captured eight juvenile Six-lined Racerunners averaging $43.84 \pm$ $5.52 \mathrm{~mm}$ for SVL and $68.74 \pm 7.19 \mathrm{~mm}$ for tail length (Table 2). This measurement is larger than previously recorded hatchling measurements, which range from 28 to $32 \mathrm{~mm}$ in SVL and 45 to $46 \mathrm{~mm}$ in tail length (Lynch 1985, Ballinger et al. 2010). However, after hibernation in early spring, Ballinger et al. (2010) recorded similar measurements of juveniles, ranging from 40 to $50 \mathrm{~mm}$. This species' tail is about twice the length of its body in adults and is about 1.6 times the length of its body in juveniles, although the tail rarely obtains its original length if lost and regenerated (Ballinger et al. 2010). Juveniles in our study closely followed these approximations, as average tail length corresponded to 1.57 times SVL. However, adults in our study generally had shorter tail to SVL ratios (1.76) than described by Ballinger et al. (2010), which may be indicative of a high rate of tail loss. 


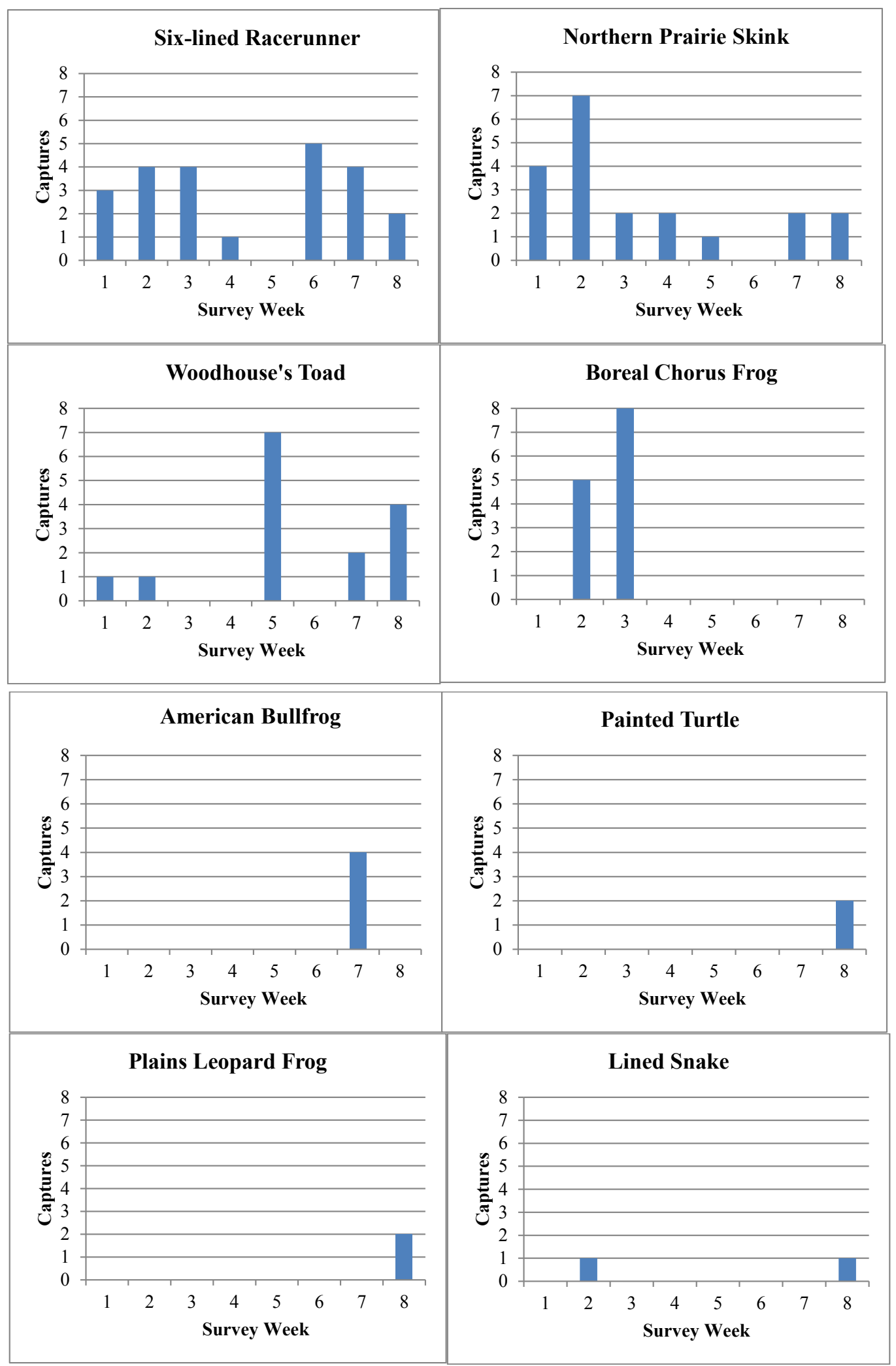

Figure 2. Herpetofauna activity patterns in the Central Platte River Valley, Nebraska. Total captures across all sites by survey week for species with 2 or more total captures. Weeks are measured from Wednesday to Wednesday (week $1=5$ to 11 June 2019 ; week $8=24$ to 30 July 2019). Some traps were closed through flooding occurring during portions of week 5 and 6 (9 to 15 July 2019 ). 
Activity Patterns - Six-lined Racerunners displayed high activity levels throughout the entire length of the study, excluding weeks 4 and 5 , which may be due in part to the flooding that occurred in week 5 (Figure 2). As mating and egg-laying are extended throughout June, July, and August, our results follow typical activity patterns for this species (Fitch 1958, Jones et al. 1981, Ballinger et al. 2010, Fogell 2010). Geluso and Harner (2013a) reported similar activity levels for this species in the CPRV as well, as Six-lined Racerunners were observed in June, July, and September.

\section{Northern Prairie Skink (Plestiodon septentrionalis)}

Habitat Associations - We captured Northern Prairie Skinks on sandy upland ridges and loamy lowland tallgrass prairies ranging from about $100 \mathrm{~m}$ north of the Platte River's north channel to $6 \mathrm{~km}$ south of the Platte River's main channel (FKR, MMR, NBR, MMP, RP; Table 1, Figure 1). This species was absent from two sites, FKP, a sandy mixed grass prairie, and SMW, a riparian woodland (Table 1, Figure 1). Northern Prairie Skinks are found in the eastern third of Nebraska, and extend west alongside the Platte River, with a distribution along the western edge of the tallgrass ecoregion and analogous habitats of the Great Plains (Scott 2005, Ballinger et al. 2010, Fogell 2010, Geluso and Harner 2013a). This species inhabits prairies and woodland edges with loose, loamy, or sandy soils (Brackenridge 1943, Jones et al. 1981, Scott 2005, Ballinger et al. 2010, Fogell 2010, Geluso and Harner 2013a, Danielsen et al. 2014). Jones et al. (1981) and Geluso and Harner (2013a) frequently observed Northern Prairie Skinks across a diverse range of grassland pastures and along ecotones of forested and grassland habitats, similar to our results. This species was absent from only two sites, which both displayed higher WISs, with FKP having a score of 4.43 and SMW having a score of 4.67 (Table 1). These systems were likely less connected to groundwater and therefore supported a more xeric flora commensurate with the regional rainfall regime (Currier 1995, Henzsey et al. 2004, Kaul et al. 2012). Our results show a marginal negative relationship between relative abundance and WIS, suggesting a potential selection against the driest sites locally by this species. It is important to note that all terrestrial sites surveyed were on the upland continuum (WIS range $=3.44$ to 4.67 ; Table 1 ), and therefore this finding may represent a selection against the driest sites rather than for the wettest. Though our study area is predominantly composed of lowland tallgrass prairie and wet meadow habitats, the highest sandy ridges tend to support a more mixed grass flora (Currier 1995, Henzsey et al. 2004, Kaul et al. 2012). It is notable that vegetative cover in tallgrass prairies generally exceeds that of drier mixed grass prairies (Lane et al. 200, Nippert et al. 2011). Danielsen et al. (2014) found, in Manitoba, a significant increase in Northern Prairie Skink captures as cover abundance per acre increased. As cover supplies food, shelter, and protection from predators for this species, limited use at certain sites or habitats may be explained by inadequate cover of live or senesced (litter) vegetation (Danielsen et al. 2014).

Morphometrics - We captured ten adult Northern Prairie Skinks averaging $59.57 \pm 3.78 \mathrm{~mm}$ for SVL and 103.89 $\pm 23.46 \mathrm{~mm}$ for tail length (Table 2). Geluso and Harner (2013a) recorded similar measurements within the CPRV with an average snout-vent length of $56.7 \pm 14.1 \mathrm{~mm}$ for all captured individuals. However, Somma (1987) documented a higher average SVL of $72.4 \mathrm{~mm}$ for adult Northern Prairie Skinks in Nebraska. Previous measurements suggest adults range from 50 to $90 \mathrm{~mm}$ in snout-vent length with males tending to be slightly smaller (50-79 $\mathrm{mm}$ ) than females (52-90 mm; Lynch 1985, Ballinger et al. 2010). These differences in averages may be due to the use of only reproductive females by Somma (1987) or a regional difference in size of this species between eastern Nebraska and the CPRV. We captured four juvenile Northern Prairie Skinks averaging $44.98 \pm 3.02 \mathrm{~mm}$ for SVL and $60.43 \pm 27.26 \mathrm{~mm}$ for tail length as well (Table 2). As hatchlings Prairie Skinks are approximately 24 to 26 $\mathrm{mm}$ in snout-vent length, these measurements may suggest that our captured juveniles were from the previous year (Ballinger et al. 2010). Tail measurements were also recorded for all captures, however, considering the frequency of autotomy and regeneration of the tail in Northern Prairie Skinks, data is mostly lacking for comparison (Ballinger et al. 2010). Lynch (1985) and Ballinger et al. (2010) indicate that the tail is about the same length as the body in juveniles but is about one to two times the length of the body in adults. Our results broadly agree with this assertion as adult tail lengths were on average 1.74 times longer than SVLs. However, the average juvenile tail length to SVL ratio was intermediate (1.34) following Ballinger et al. (2010), supporting our hypothesis that juveniles may represent individuals born during the previous year's growing season.

Activity Patterns - Northern Prairie Skinks appeared most active during the beginning of June, but captures occurred throughout the study (Figure 2). This perceived 
spike in activity in early June (i.e. week 1 and 2) corresponds with the mating season of this species, as breeding occurs in late May with oviposition following 2 to 3 weeks later in mid to late June (Somma 1987, Ballinger et al. 2010, Fogell 2010, Geluso and Harner 2013a). Geluso and Harner (2013a) recorded the greatest number of captures of this species in June as well, crediting the Northern Prairie Skinks' increased activity to movement related to mating and nest cavity construction. Activity markedly drops after mating as both sexes restrict movements with females focusing on brooding their eggs (Scott 2005). Northern Prairie Skink activity levels are not reported to increase again until after young hatch, which may explain lower capture rates between weeks 3 and 8 (Scott 2005; Figure 2).

\section{Woodhouse's Toad (Anaxyrus woodhousii)}

Habitat Associations - We captured Woodhouse's Toads (i.e. fifteen individuals) in a sandy mixed grass prairie about $6 \mathrm{~km}$ south of the Platte River near Fort Kearny (FKP; $40.602667^{\circ} \mathrm{N}, 99.008383^{\circ} \mathrm{W}$ ) and in a sandy upland ridge about $400 \mathrm{~m}$ south of the Platte River (MMR; $40.772567^{\circ} \mathrm{N}, 98.475050^{\circ} \mathrm{W}$; Table 1, Figure 1). Our results indicated abundance was positively associated with bare ground percentage, which is similar to findings by Grant et al. (2015) suggesting bare ground was the strongest habitat correlate of Woodhouse's Toad site occupancy. The prairie site dominated by Japanese Bristlegrass (Setaria faberi) and American Bird's-foot Trefoil (Lotus purshianus), was composed of a FACU-UPL plant community (WIS=4.43; Table 1). The ridge site was dominated by Sand Lovegrass (Eragrostis trichodes) and Purple Poppy Mallow (Callirhoe involucrata), supporting a FAC-FACU plant community (WIS=3.67; Table 1). As this species is considered to be the most abundant toad in Nebraska with relatively broad habitat requirements, these findings are not surprising (Hudson 1985, Ballinger et al. 2010). Woodhouse's Toads have been found in a variety of habitats ranging from relic mixed grass prairies and woodland edges to human settlements (Bragg 1940, Ballinger 1980, Jones et al. 1981, Ballinger et al. 2010, Fogell 2010, Geluso and Harner 2013a). A preference for loose or sandy soil near water has been previously indicated which is exhibited in our results as well, as both sites where this species was captured were composed of sandy soil (Ballinger et al. 2010, Fogell 2010; Table 1). This species will also breed in most bodies of water, as they are not dependent on rainfall for reproduction, and both sites were in close proximity to standing water (i.e. prairie $=11 \mathrm{~m}$, ridge $=37.5$ m, Table 1; Bragg 1940, Ballinger 1980, Jones et al. 1981, Geluso and Harner 2013a).

Morphometrics - The majority of our Woodhouse's Toad captures were juveniles (i.e. 14 out of 15), with a SVL averaging around $25.15 \mathrm{~mm} \pm 6.77 \mathrm{~mm}$ (Table 2). Geluso and Harner (2013a) recorded similar measurements in the CPRV, as all juveniles captured had a SVL $\leq 35 \mathrm{~mm}$. Similarly to Geluso and Harner (2013a), our first detections of juvenile Woodhouse's Toads in July measured about $20 \mathrm{~mm}$. Woodhouse's Toads in South Dakota measured similarly $(\bar{x}=27.3 \mathrm{~mm}$ SVL) for individuals that metamorphosed in June (Underhill 1960). However, Underhill (1960) noted that larger individuals captured in June were between 25 and $50 \mathrm{~mm}$, as these individuals were considered to be born the previous year and not fully developed to adult size ranges. Our juvenile captures in June were also between 25 and $50 \mathrm{~mm}$, which may suggest that Woodhouse's Toads in Nebraska occasionally require two years to fully mature like the individuals in South Dakota (Underhill 1960). This may be related to regional differences (i.e. climatic influences, etc.), as the growth rate of this species in South Dakota is approximately half that for individuals in Oklahoma (Bragg 1940, Underhill 1960). However, this represents a preliminary hypothesis for future testing and not a substantiable inference considering the limited amount of pertinent data collected during this study. The largest Woodhouse's Toad captured, and only adult, had a snout-vent length of $60.9 \mathrm{~mm}$.

Activity Patterns - The month of July appeared to be the most active time for Woodhouse's Toads based on our total captures across all sites (Figure 2). It is important to note that even though this species is not dependent on rain for reproduction, activity levels increase during and shortly after rain events (Bragg 1940, Ballinger 1980, Jones et al. 1981, Goldowitz and Whiles 1999). Woodhouse's Toads emerge in early to mid-April and remain relatively active until October, with early activity dependent on mild winter temperatures and late activity levels generally decreasing as fall weather begins (Ballinger et al. 2010, Fogell 2010). The previous winter and spring prior to our study were abnormally cold and wet which may have delayed breeding in $\mathrm{Ne}-$ braska, as Underhill (1960) mentioned a similar occurrence with dry springs and cold nights in South Dakota. However, as Geluso and Harner (2013a) reported, this species was also most active in July during their study. Though temperatures may impact emergence timing it 
appears that Woodhouse's Toads may consistently be most active in the middle of the summer in the CRPV, at least in terms of movement.

\section{Boreal Chorus Frog (Pseudacris maculata)}

Habitat Associations - We captured Boreal Chorus Frogs in a loamy, lowland tallgrass prairie, hosting a facultative upland plant community with a WIS of 4.00 (Table 1). This species was only detected at a site about $400 \mathrm{~m}$ south of the Platte River (MMP; $40.771767^{\circ} \mathrm{N}$, 98.475967 W) with Big Bluestem (Andropogon gerardii) as the dominant grass and Whorled Milkweed (Asclepias verticillata) as the dominant forb (Table 1, Figure 1 ). As habitat generalists, Boreal Chorus Frogs are abundant statewide in a broad range of habitats from open woodlands to grasslands near small bodies of temporary water (Ballinger 1980, Jones et al. 1981, Ballinger et al. 2010, Fogell 2010, Mushet et al. 2012, Geluso and Harner 2013a). Geluso and Harner (2013a) found this species most abundant in shallow and intermittent bodies of water, likely reflecting an avoidance of water inhabited by predatory fish and Bullfrogs (Ballinger et al. 2010). Our data suggested that Boreal Chorus Frog relative abundance may be positively related to the distance of a site from woodland habitat, corresponding with previously noted preferences of this species for grassland habitats in Nebraska (Ballinger et al. 2010; Table 1).

Morphometrics - All of our Boreal Chorus Frog captures were juveniles with an SVL averaging around 14.82 $\pm 0.26 \mathrm{~mm}$ (Table 2). Previous measurements from Fogell (2010) suggest that adults of this species in Nebraska do not exceed more than $33 \mathrm{~mm}$ in length, with Lynch (1985) recording males averaging $26 \mathrm{~mm} \mathrm{SVL}$ and females averaging $28 \mathrm{~mm}$ SVL. Ballinger et al. (2010) noted that Western Chorus Frogs (Pseudacris triseriata, sensu lato, includes P. maculata; Lemmon et al. 2007) in Nebraska appear to vary geographically in size, with the eastern populations recording larger adult average measurements (i.e. males $=26.3 \mathrm{~mm}$, females $=27.8 \mathrm{~mm}$ ) than western populations (i.e. males $=24.5 \mathrm{~mm}$, females $=26.4 \mathrm{~mm}$ ). While body size has been found to be an inadequate indicator of age for mature male Boreal Chorus Frogs, the large difference between our results and previous reports is likely due to a difference in maturity level (i.e. juvenile vs. adult). Captures during our study corresponded with the time of emergence for this species from metamorphosis, when they generally range from 7.5 to $11 \mathrm{~mm} \mathrm{SVL}$, suggesting that the Boreal
Chorus Frogs captured in our study were likely just beyond metamorphosis in age (Ballinger et al. 1979, Lynch 1985, Platz and Lathrop 1993, Ballinger et al. 2010).

Activity Patterns - The month of June, particularly weeks 2 and 3, resulted in our only captures of Boreal Chorus Frogs (Figure 2). Goldowitz and Whiles (1999) documented peaks in activity in April and November, however, our shorter study did not evaluate those time periods. Geluso and Harner (2013a) recorded the greatest number of captures in July. However, as Boreal Chorus Frogs reproductive activity is generally continuous from early March through late May, with heavy thunderstorms reopening the breeding season occasionally, our recorded high activity level is most likely due to the emergence of new metamorphs (Jones et al. 1981, Ballinger et al. 2010, Fogell 2010, Geluso and Harner 2013a, Brinley Buckley et al. 2021; Figure 2). Geluso and Harner (2013a) noted similar findings as the majority of their captures in July were of recent metamorphs.

\section{American Bullfrog (Lithobates catesbeianus)}

Habitat Associations - We captured American Bullfrogs in a sandy, mixed grass prairie, hosting a facultative upland plant community with a WIS of 4.43 (Table 1). This species was only detected at a site about $6 \mathrm{~km}$ south of the Platte River near Fort Kearny (FKP; $40.602667^{\circ} \mathrm{N}$, $99.008383^{\circ} \mathrm{W}$ ) with Japanese Bristlegrass as the dominant grass and American Bird's-foot Trefoil as the dominant forb (Table 1, Figure 1). The native distribution for this species in Nebraska is unknown, due to active stocking programs, resulting in a range throughout the state (Lynch 1985, Ballinger et al. 2010, Fogell 2010). As American Bullfrog tadpoles overwinter, this species is dependent on permanent bodies of water for habitat (Ballinger et al. 2010, Fogell 2010, Geluso and Harner 2013a). Shulse et al. (2010) found that this species was abundant in wetlands with open ponds possessing permanent hydrology and increasing slope. Our results showed that American Bullfrog capture rates decreased as distance to water increased and capture rates increased with vegetation species richness as well as exotic species cover. However, similarly to the habitat correlates we observed regarding Plains Leopard Frogs, the associations with vegetative community characteristics are likely indirect and more reflective of widely fluctuating hydrological disturbances than floral diversity or exotic species cover (Ward et al. 1999, Casanova and Brock 2000, Davis et al. 2000). As this species frequents permanent bodies of water, the close 
proximity to semi-permanent water (dist. $=11.0 \mathrm{~m}$ ) at this site is moderately surprising (Table 1). However, as Gahl et al. (2009) found, American Bullfrogs regularly use temporary wetlands, and suggested that the importance of this non-breeding habitat is due to predation protection, intraspecific competition, or as stepping stones for dispersal and migration.

Activity Patterns - The end of July, within week 7, resulted in our only captures of American Bullfrogs, indicating a higher activity level based on captures across all sites (Figure 2). This compares to the recorded breeding season of this species, which extends from May through July, as American Bullfrogs begin breeding later than all other anurans in Nebraska (Ballinger et al. 2010, Fogell 2010). However, the captures may instead be related to the flooding that occurred throughout the CPRV during weeks 5 and 6 , as this species is known to make extensive migrations to different bodies of water during precipitation events (Fogell 2010).

\section{Painted Turtle (Chrysemys picta)}

Habitat Associations - We captured two Painted Turtles at South Brown slough $\left(40.790600^{\circ} \mathrm{N}, 98.468550^{\circ} \mathrm{W}\right)$ about $850 \mathrm{~m}$ north of the Platte River's main channel (Appendix 1). This species is distributed statewide in Nebraska, inhabiting nearly any permanent aquatic habitat (Jones et al. 1981, Lynch 1985, Ballinger et al. 2010, Fogell 2010, Geluso and Harner 2013a). While Painted Turtles mainly associate with ponds and lakes, slow-moving streams and sloughs also provide acceptable habitat (Jones et al. 1981, Fogell 2010, Geluso and Harner 2013a). Geluso and Harner (2013a) previously observed Painted Turtles on logs within South Brown slough as well.

Activity Patterns - The end of July, within week 8, resulted in all of our Painted Turtle captures (Figure 2). Painted Turtle activity levels increase with water temperatures above $10^{\circ} \mathrm{C}$, but this species can regularly be found from March through mid-October (Ernst 1971, Fogell 2010). Mating occurs from late April to mid-June, with the nesting season extending from June to July (Ernst 1971, Ballinger et al. 2010, Fogell 2010). The concentration of our results during week 8 may be due to increased movement associated with nesting season or the heavy precipitation event that occurred which altered the habitat, as multiple trees were uprooted along the slough.

\section{Plains Leopard Frog (Lithobates blairi)}

Habitat Associations - Plains Leopard Frogs were captured in a sandy mixed grass prairie, hosting a facultative upland plant community (WIS=4.43), about $6 \mathrm{~km}$ south of the Platte River near Fort Kearny (FKP; $40.602667^{\circ} \mathrm{N}$, $99.008383^{\circ} \mathrm{W}$; Table 1, Figure 1). The site was dominated by Japanese Bristlegrass and American Bird's-foot Trefoil and was within close proximity to semi-permanent water and relatively far from a woodland (wetland dist. $=11.0$ $\mathrm{m}$, woodland dist. $=238.5 \mathrm{~m}$; Table 1). As Plains Leopard Frogs are generally associated with grasslands and shallow bodies of water throughout eastern and southern Nebraska, our results correspond with previously recorded habitat characteristics for this species (Lynch 1978, Jones et al. 1981, Brown 1992, Ballinger et al. 2010, Fogell 2010, Shulse et al. 2010, Geluso and Harner 2013a; Table 1). Interestingly, our results also demonstrated a positive relationship between Plains Leopard Frog abundance and vegetative species richness as well as exotic plant cover. However, this is likely an indirect relationship reflective of their respective associations with a dynamic ecotone. The FKP site exists along the upland edge of an ecotone between aquatic and terrestrial environments, where the wetland experiences widely fluctuating hydrology, which has been linked to high vegetative diversity and occasionally biological invasions of exotic vascular plants (Ward et al. 1999, Casanova and Brock 2000, Davis et al. 2000). Upland buffer areas surrounding wetlands are essential to supporting amphibian life histories, protecting water quality, and reducing unnatural rates of wetland sedimentation (Reddy and Gale 1994, Gleason and Euliss 1998, Semlitsch et al. 2003). Therefore, it is not surprising we detected Plains Leopard Frogs in this wetlandadjacent zone.

The location of Plains Leopard Frogs within a predominantly sandy soil area contrasts with the ecologic partition that is found between this species and Northern Leopard Frogs (Lithobates pipiens; Lynch 1978, Lynch 1985, Ballinger et al. 2010). These two species have been found to select for different substrates, with Plains Leopard Frogs preferring loess soils while Northern Leopard Frogs predominate in sandy soils (Lynch 1978, Lynch 1985, Ballinger et al. 2010). The CPRV is near the southern edge of the Northern Leopard Frog's geographic range, which appears to be contracting as a result of several factors, and is well within but toward the northern end of the Plains Leopard Frog range (Smith and Keinath 2007, Ballinger et al. 2010). Christian and 
Bailey (1991) suggest that both species may exist in recently re-inundated wetlands in regions where the species are sympatric, particularly before one species can displace the other. Relatedly, Dunlap and Kruse (1976) documented hybrids of Northern and Plains Leopard Frogs in the Platte River Valley, which had intermediate physical characteristics between the two species. This species was the most abundant herptile on Crane Trust lands per Jones et al. (1981) and the fourth most encountered species by Geluso and Harner (2013). However, our study's only captures occurred off Crane Trust property. This is likely a result of site selection as we placed pitfall traps at terrestrial locations that were categorically non-wetland, and did not employ anuran-focused traps at aquatic (permanent wetland) sites. Unsurprisingly, the site at which we detected Plains Leopard Frogs (FKP) was the closest to water (11 m; Table 1).

Morphometrics - We captured a total of two juvenile Plains Leopard Frog individuals, averaging $41.40 \pm 2.40$ $\mathrm{mm}$ for SVL (Table 2). Newly metamorphosed juveniles of this species have been recorded ranging $28-30 \mathrm{~mm}$, with adults in Nebraska measuring between 50-101 mm for SVL (Lynch 1985, Ballinger et al. 2010, Fogell 2010, Geluso and Harner 2013a). It is notable that our results are again intermediate between these two life stages, as they have been regarding most of our anuran species. Wells (2010) indicates that dispersal is more frequently observed regarding juvenile anurans. It is possible that several species of anurans in the CPRV are dispersing across upland habitats following an initial period of growth and development in their natal wetlands (Wells 2010). Comparatively, our results appear larger than average for juveniles, which may be explained by a percentage of the tadpoles overwintering and metamorphosing during early spring (Ballinger et al. 2010, Fogell 2010). Interestingly, Geluso and Harner (2013a) found that the average SVL of all Plains Leopard Frogs trapped in their study was $38.1 \pm 11.6 \mathrm{~mm}$, which consisted mostly of juveniles, indicating that the pattern of physiological development observed in our study may be common regionally.

Activity Patterns - The last week of the study (end of July) resulted in our only captures of Plains Leopard Frogs (Figure 2). Brown (1992) found that, depending on local environmental conditions, breeding for this species can occur from February through October. However, in Nebraska the breeding season is relatively constricted, with the majority of breeding activity occurring from March to May and periodically extending throughout the summer based on precipitation events (Lynch
1978, Jones et al. 1981, Ballinger et al. 2010). Our results likely reflect the time of metamorphosis for Plains Leopard Frogs from tadpoles to juveniles, as previous records note newly metamorphosed frogs from mid-June to August (Jones et al. 1981, Fogell 2010, Geluso and Harner 2013a). Geluso and Harner (2013a) observed similar findings as their greatest number of captures occurred in July, consisting mostly of juveniles.

\section{Lined Snake (Tropidoclonion lineatum)}

Habitat Associations - Lined Snakes were captured in loamy, lowland tallgrass prairies about $400 \mathrm{~m}$ south (MMP; $40.771767^{\circ} \mathrm{N}, 98.475967^{\circ} \mathrm{W}$ ) and about $1.2 \mathrm{~km}$ north of the Platte River's main channel (RP; $40.787417^{\circ} \mathrm{N}$, $98.484267^{\circ} \mathrm{W}$; Table 1, Figure 1). The MMP site was dominated by Big Bluestem, Whorled Milkweed, and composed of a facultative upland plant community (WIS $=4.00$; Table 1). The RP site was dominated by Smooth Brome (Bromus inermis) and White Heath Aster (Aster ericoides), but also included a codominant $A$. gerardii component, and supported a facultative plant community (WIS $=3.44$; Table 1). Found mainly in eastern and southeastern Nebraska, with westward distribution along the Platte River, this species inhabits prairies, savannas, and woodland edges (Ballinger et al. 2010, Fogell 2010, Geluso and Harner 2013a). The Lined Snake demonstrated no significant preferences in our analysis (Table 1). Fogell (2010) noted that Lined Snakes occur most frequently near wetland associations. However, Geluso and Harner (2013a) observed this species most often in uplands (i.e., grasslands) as compared to wetlands (i.e., sloughs). Nonetheless, this seeming contradiction makes sense when one considers the character of habitat within the CPRV (Currier 1995, Henszey et al. 2004). Wetland habitats of varying size exist within a grassland matrix where small elevational changes can result in significant hydrological shifts across a short lateral distance (Currier 1995, Henszey et al. 2004). Our results provide some support for this assertion as Lined Snakes were most common at sites with significant Big Bluestem cover, which is regionally abundant as a result of the shallow groundwater provided by the Platte River (Currier 1995, Henszey et al. 2004, Kaul et al. 2012). This species is often dominant or codominant in subirrigated lowland tallgrass prairies, which are topographically just above wetland habitats such as wet meadows and support a more mesic flora than would result from the regional rainfall regime alone (Currier 1995, Henszey et al. 2004, Kaul et al. 2012; Table 1). 
Activity Patterns - Lined Snakes were captured in the middle of June and at the end of July, indicating that this species is relatively active throughout a significant portion the summer (Figure 2). Ballinger et al. (2010) and Fogell (2010) have both observed similar behavior as this cold-tolerant species emerges in late March and remains active until October.

\section{Common Lesser Earless Lizard (Holbrookia maculata)}

Habitat Associations - Our only captured individual was found on a sand ridge prairie about $6 \mathrm{~km}$ south of the Platte River near Fort Kearny (FKR; $40.602917^{\circ} \mathrm{N}$, $99.008300^{\circ} \mathrm{W}$; Table 1, Figure 1). The site was dominated by Prairie Sand Reed (Calamovilfa longifolia) and Western Ragweed (Ambrosia psilostachya; Table 1), supporting a predominantly facultative upland plant community (WIS $=4.2$; Table 1). Research indicates that Common Lesser Earless Lizards prefer upland habitats with sandy soils and sparse vegetation in the Great Plains (Ballinger et al. 1979, Lynch 1985, Ballinger and Watts 1995, Rogers 2018). Our results are typical in that this upland habitat contained sandy soils but atypical in that the site had $80 \%$ vegetative cover within the $0.5 \mathrm{~m}$ to $2.0 \mathrm{~m}$ height range, and only 10\% bare ground. Ballinger and Watts (1995) found that the Common Lesser Earless Lizard, in a Sandhills prairie in Nebraska, decreased markedly within one decade following the removal of cattle grazing and concurrent increase in vegetative cover. By targeting areas without cattle grazing, it is possible that our capture rates of this species were artificially low. As Lynch (1985) notes this species is not common within river corridors. This unique detection demonstrates the presence of relatively isolated occurrences in remnant Sandhills prairies south of the Platte River, which likely existed just outside of the historic floodplain (Williams 1978, Fogell 2010, Kaul et al. 2012). These prairie fragments exist in a relative sea of agriculture within one of the most productive corn and soybean growing areas within the Great Plains (Dappen et al. 2008, Thormodsgard 2009). Rotational grazing may help maintain isolated populations of Common Lesser Earless Lizards in these unique and remote environments (Ballinger and Watts 1995).

\section{Cope's Gray Treefrog (Hyla chrysoscelis)}

Habitat Associations - We captured one adult Cope's Gray Treefrog $(\mathrm{SVL}=34.30 \mathrm{~mm})$ in a loamy, lowland tallgrass prairie about $400 \mathrm{~m}$ south of the Platte River (MMP; $40.771767^{\circ} \mathrm{N}, 98.475967^{\circ} \mathrm{W}$; Table 1, Table 2, Figure 1). The prairie was dominated by Big Bluestem and Whorled Milkweed and supported a predominantly facultative upland plant community (WIS=4.00; Table 1). Cope's Gray Treefrogs have a historic distributional limit at southeastern Nebraska and show a preference for riparian woodlands and oak savannas near ephemeral and permanent bodies of water (Pittman et al. 2008, Ballinger et al. 2010, Fogell 2010, McLean et al. 2015). Interestingly, the site where we captured the Cope's Gray Treefrog was the furthest distance to a woodland (dist. $=731 \mathrm{~m}$ ) of all our sites. A small grouping of isolated trees nearby (dist. $=70 \mathrm{~m})$, despite no identification as a woodland, may have provided acceptable habitat for this species (Table 1). However, McLean et al. (2015) recorded this species a considerable distance $(\sim 260 \mathrm{~m})$ from woodland habitat in the CPRV vocalizing from a Smooth Brome culm about $24 \mathrm{~m}$ from the nearest wetland in late June of 2014. Similarly, Jaslow and Vogt (1977) found this highly arboreal species to inhabit grasslands in Wisconsin on the western edge of its range.

Our Cope's Gray Treefrog capture was from a prairie across the main channel of the Platte River from where McLean et al. (2015) located this species. This suggests Cope's Gray Treefrogs are relatively widespread locally, as they have now been detected north and south of the main channel of the Platte River (>300 m channel width in this area; Caven et al. 2019b), and on island as well as non-island habitats. Considerable debate exists regarding the nature of recent detections of Cope's Gray Treefrogs west of their historic range, particularly along the Platte River (Ballinger et al. 2010, McLean et al. 2015, Tye et al. 2017, Carlson and Geluso 2018). It is unclear if the detected individuals represent a disjunct population that was previously undetected, were introduced through human action (mechanically assisted dispersal), or if recent detections represent range expansion associated with habitat change (e.g. - increased tree cover), climatic shifts (e.g. - increased annual minimum temperatures), or a combination of factors (Fogell 2010, McLean et al. 2015, Tye et al. 2017, Carlson and Geluso 2018). Data from recent call surveys conducted at Mormon and Shoemaker Islands from 2018 to 2020 suggest that Cope's Gray Treefrogs are relatively widespread across both islands, indicating that regardless of their origin, the species may be becoming locally prevalent in a way they were not historically (Ballinger 1980, Ballinger et al. 2010, Geluso and Harner 2013a, Caven and Malzahn 2019, Caven 2020). 


\section{Plains Gartersnake (Thamnophis radix)}

Habitat Associations - We captured one Plains Gartersnake in a sandy, upland ridge about $100 \mathrm{~m}$ north of the Platte River's north channel (NBR; $40.798600^{\circ} \mathrm{N}, 98.469850^{\circ} \mathrm{W}$; Table 1, Figure 1). The ridge was dominated by Smooth Brome and Western Ragweed, hosting a predominantly facultative upland plant community (WIS=3.75; Table 1). As the most common snake species in Nebraska, the Plains Gartersnake is distributed statewide with preferred habitat found in prairies with wetland associations, such as river valleys, ponds, lakes, marshes, and sloughs (Jones et al. 1981, Lynch 1985, Ballinger et al. 2010, Fogell 2010, Geluso and Harner 2013a). As we only captured a single Plains Gartersnake it is hard to make inferences about habitat associations as well as activity patterns. However, the site and time period in which this species was captured are reflective of previously documented habitat preferences and activity patterns (Ballinger et al. 2010; Table 1). For instance, this site (NBR) was just over $15 \mathrm{~m}$ from a wetland slough.

\section{Study Limitations}

This study represents an initial attempt to quantify some of the habitat associations of CPRV herptiles. However, our sites did not represent the full range of hydrological variability in the CPRV. A majority of terrestrial sites existed across an upland continuum including lowland tallgrass prairie, woodland, sand ridge prairie, and mixed grass prairie, and aquatic sampling sites included permanent sloughs and a pond. However, the CPRV is known for having a broad swath of transitional habitats including temporary and semipermanent wetlands such as wet meadows and shallow marshes, which provide preferred habitat for several anuran species (Goldowitz and Whiles 1999). These habitats were notably absent from our sampling scheme. This likely explains the absence of Plains Leopard Frogs from most of our sampling sites on Mormon and Shoemaker Islands where they have been commonly recorded in past studies (Goldowitz and Whiles 1999, Geluso and Harner 2013). A large number of anurans detected during our study may well represent dispersals, which would align with the high number of juveniles we captured (Wells 2010). Our study represents a relatively modest and exploratory effort covering 11 sites (7 terrestrial, 4 aquatic) and employing a diversity of trap types including funnel, pitfall, hoop, box, and cover board traps. Abundance estimates may be biased as we simply presented captures per unit effort during this study and did not use mark-recapture techniques (White and Burnham 1999). Moreover, a single array cannot reliably sample species presence, absence, or abundance at an entire site and some individuals and/or species were certainly missed. These study limitations, however, do not negate the habitat associations, morphometric characteristics, or activity patterns of the species detected, but inferences based upon our exploratory results should be carefully applied and limited in scope. Caution may be particularly important regarding morphometric measurements, as these are ectothermic species influenced by environmental conditions and data were collected during only a single growing season. Another limit to our study design was that not all trap types were deployed at all sites; we attempted to account for this statistically but there is still a possibility that site-level factors influenced our estimates of capture success per trap type (Mengak and Guynn 1987). Given our small sample size and the fact we did not sample across a complete hydrological gradient, our findings should be interpreted with some caution and only within the contexts of the existing literature.

\section{Conclusions}

Our findings indicate that the Northern Prairie Skink is one of our most widely distributed species and likely selects against the driest terrestrial sites in the CPRV. The Six-lined Racerunner, by contrast, is locally abundant in appropriate habitat with significant bare ground and is likely associated with more xeric landscape features and sandy soils. Additional findings of note include the discovery of a Cope's Gray Treefrog in a prairie dominated site where they had not been previously detected, providing further evidence of this species' increasingly widespread distribution in the CPRV. Additionally, we documented a Common Lesser Earless Lizard in an isolated Sandhills mixed grass prairie remnant south of the Platte River just outside of the historic floodplain. For four of the five anuran species detected, we predominantly captured juveniles. Given that we trapped categorically upland sites, this fits with the conclusions of Wells (2010) that juvenile anurans may be more likely than adults to disperse relatively widely across terrestrial habitats. Though upland grassland habitats may appear less important than wetlands to anuran populations they provide important dispersal and migration corridors that keep populations 
genetically connected (Semlitsch et al. 2003). These findings underscore the importance of maintaining a mosaic of habitats to sustain a dynamic and diverse herpetofauna community, where individual species demonstrate unique habitat associations, often specific to developmental stage. Our exploratory analyses provide insights into species development, habitat associations, and herpetofauna ecology in the CPRV, but more intensive work is certainly needed. We recommend more exhaustive studies across a wider range of both private and conservationowned properties in the CPRV to fully document the extant herpetofauna community regionally. Secondly, we recommend sampling across the diversity of soil types and flooding frequencies documented in the CPRV.

\section{Acknowledgements}

We want to thank the Cabela's Apprenticeship Program and the Crane Trust for funding this project, as well as Brice Krohn for helping coordinate logistics. The authors' roles were as follows: D. Ferraro- funding, equipment, review; B. Ostrom- implementation, writing, review; J. Malzahn- implementation, writing, review, coordination; A.J. Caven- sampling design, analysis, writing, review, implementation, and revisions; S. Warren- sampling design, data collection, implementation, writing, and coordination. We want to thank Dr. Karen Murch-Shafer, Dr. Mark Schoenbeck, and two anonymous reviewers for excellent critiques and editorial suggestions regarding this manuscript.

\section{Literature Cited}

Allen RP. (1952) The Whooping Crane. Research Report No. 3, National Audubon Society, New York, NY, 246 pp.

Ballinger RE. (1980) Amphibians and reptiles of Mormon Island preserve. Report submitted to The Nature Conservancy, Grand Island, NE, USA, 53 pp.

Ballinger RE, Lynch JD, and Smith GR. (2010) Amphibians and reptiles of Nebraska (Lincoln, NE: University of Nebraska Press).

Ballinger RE, Lynch JD, and Cole PH. 1979. Distribution and Natural History of Amphibians and Reptiles in Western Nebraska with Ecological Notes on the Herpetiles of Arapaho Prairie. The Prairie Naturalist 11(3): 65-74.

Ballinger RE. and Watts KS. (1995) Path to extinction: impact of vegetational change on lizard populations on Arapaho Prairie in the Nebraska Sandhills. The American Midland Naturalist 134(2): 413-417.
Bragg A. (1940) Observations on the Ecology and Natural History of Anura II. Habits, Habitat, and Breeding of Bufo woodhousii woodhousii (Girard) in Oklahoma. The American Midland Naturalist 24(2): 306-321.

Breckenridge WJ. (1943) The life history of the black-banded skink Eumeces septentrionalis septentrionalis (Baird). The American Midland Naturalist 29: 591-606.

Brinley Buckley EM, Gottesman BL, Caven AJ, Harner MJ, and Pijanowski BC. (2021) Assessing ecological and environmental influences on boreal chorus frog (Pseudacris maculata) spring calling phenology using multimodal passive monitoring technologies. Ecological Indicators 121: 107171.

Brooks T, Da Fonseca GA, and Rodrigues AS. (2004) Species, data, and conservation planning. Conservation Biology 18(6): 1682-1688.

Brown LE. (1992) Rana blairi. Catalogue of American Amphibians and Reptiles 536: 1-6.

Carlson ZA and Geluso K. (2018) Second sighting of Cope's Gray Treefrog (Hyla chrysoscelis) in Buffalo County, Nebraska. Collinsorum 7: 18.

Casanova MT and Brock MA. (2000) How do depth, duration and frequency of flooding influence the establishment of wetland plant communities? Plant Ecology 147(2): 237-250.

Caven AJ, King KC, Wiese JD, and Brinley Buckley EM. (2017b) A descriptive analysis of Regal Fritillary (Speyeria idalia) habitat utilizing biological monitoring data along the big bend of the Platte River, NE. Journal of Insect Conservation 21(2): 183-205.

Caven AJ, Salter J, and Geluso K. (2017a) Opheodrys vernalis (Liochlorophis vernalis) (Smooth Greensnake). Fire mortality and phenology. Herpetological Review 48(4): 864-865.

Caven AJ, Brinley Buckley EM, Wiese JD, Taddicken B, Krohn B, Smith TJ, and Pierson A. (2019a) Appeal for a Comprehensive Assessment of the Potential Ecological Impacts of the Proposed Platte-Republican Diversion Project. Great Plains Research 29(2): 123-135.

Caven AJ, Brinley Buckley EM, King KC, Wiese JD, Baasch DM, Wright GD, Harner MJ, Pearse AT, Rabbe M, Varner DM, Krohn B, Arcilla N, Schroeder KD, and Dinan KF. (2019b) Temporospatial shifts in Sandhill Crane staging in the Central Platte River Valley in response to climatic variation and habitat change. Monographs of the Western North American Naturalist 11(1): 33-76.

Caven AJ and Malzahn JM. (2019) 2019 Species Detection, Collection, and Monitoring Report. Crane Trust, Wood River, NE, 19 pp.

Caven AJ. (2020) 2020 Species Detection, Collection, and Monitoring Report. Crane Trust, Wood River, Nebraska, USA, 19 pp.

Chavez-Ramirez F and Wehtje W. (2012) Potential Impact of Climate Change Scenarios on Whooping Crane Life History. Wetlands 32: 11. 
Christiansen JL and Bailey RM. 1991. The salamanders and frogs of Iowa. Nongame Technical Series, No. 2, Iowa Department of Natural Resources, Des Moines, IA.

Corn PS. (1994) Straight-line drift fences and pitfall traps. In R. Heyer and M.A. Donnelly (Editors), Measuring and monitoring biological diversity: standard methods for amphibians, pp. 109-117 (Washington D.C.: Smithsonian Institution Press).

Currier PJ. (1982) The floodplain vegetation of the Platte River: phytosociology, forest development, and seedling establishment. Dissertation, Iowa State University, Ames, IA, 332 pp.

Currier PJ. (1995) Relationships between vegetation, groundwater hydrology, and soils on Platte River wetland meadows. Proceedings of the Platte River Basin Ecosystem Symposium 6: 172.

Danielsen AK, Rutherford P, and Koper N. (2014) The Importance of Vegetation Structure and Artificial Cover for Prairie Skinks (Plestiodon septentrionalis) on Exurban Land. Journal of Herpetology 48(1): 67-73.

Dappen PR, Ratcliffe IC, Robbins CR, and Merchant JW. (2008) Mapping Agricultural Land Cover for Hydrologic Modeling in the Platte River Watershed of Nebraska. Great Plains Research 18(1): 39-52.

Davis MA, Grime JP, and Thompson K. (2000) Fluctuating resources in plant communities: a general theory of invasibility. Journal of ecology 88(3): 528-534.

Dormann CF, Elith J, Bacher S, Buchmann C, Carl G, Carré G, Garcia Marquéz JR, Gruber B, Lafourcade B, Leitao PJ, Münkemüller T, McLean C, Osborne PE, Reineking B, Schroder B, Skidmore AK, Zurell D, and Lautenbach S. (2013) Collinearity: a review of methods to deal with it and a simulation study evaluating their performance. Ecography 36(1): 27-46.

Dunlap DG and Kruse KC. (1976) Frogs of the Rana pipiens complex in the northern and central plains states. The Southwestern Naturalist 20(4): 559-571.

Ernst CH. (1971) Population dynamics and activity cycles of Chrysemys picta in southeastern Pennsylvania. Journal of Herpetology 5: 151-160.

Fogell D. (2010) A field guide to the amphibians and reptiles of Nebraska. Conservation and Survey Division, School of Natural Resources, University of Nebraska-Lincoln, Lincoln, NE, 156 pp.

Fitch HS. (1958) Natural History of the Six-Lined Racerunner (Cnemidophorus sexlineatus). University of Kansas Publications - Museum of Natural History 11: 11-62.

Geluso K and Harner MJ. (2013a) Reexamination of herpetofauna on Mormon Island, Hall County, Nebraska, with notes on natural history. Transactions of the Nebraska Academy of Sciences 33: 7-20.

Geluso K. and Harner MJ. (2013b) Nerodia clarkii clarkii (Gulf
Saltmarsh Watersnake): Predation. Herpetological Review 44: 156-157.

Geluso K, Krohn BT, Harner MJ, and Assenmacher MJ. (2013) Whooping Cranes consume Plains Leopard Frogs at migratory stopover sites in Nebraska. The Prairie Naturalist 45: 91-93.

Gleason RA and Euliss Jr. NH. (1998) Sedimentation of prairie wetlands. Great Plains Research 8: 97-112.

Goldowitz BS and Whiles MR. (1999) Investigations of fish, amphibians, and aquatic invertebrate species within the Middle Platte River system. Final Report for Cooperative Agreement X99708101 with the US Environmental Protection Agency, University of Nebraska-Lincoln, Platte Watershed Program, Lincoln, NE, 32 pp.

Grant TJ, Otis DL, and Koford RR. (2015) Short-term anuran community dynamics in the Missouri River floodplain following an historic flood. Ecosphere 6(10): 197. http:// dx.doi.org/10.1890/ES15-00011.1

Harrell F. (2016) Hmisc: Harrell Miscellaneous. R package version 3.17-4. http:/ / CRAN.R-project.org/ package $=$ Hmisc

Henszey RJ, Pfeiffer K, and Keough JR. (2004) Linking surfaceand ground-water levels to riparian grassland species along the Platte River in central Nebraska, USA. Wetlands 24: 665-687.

Hudson GE. (1985) The Amphibians and Reptiles of Nebraska. Nebraska Conservation Bulletin No. 24, Conservation and Survey Division, University of Nebraska-Lincoln, Lincoln, NE, 147 pp.

Jaslow AP and Vogt RC. (1977) Identification and distribution of Hyla versicolor and Hyla chrysoscelis in Wisconsin. Herpetologica 33: 201-205.

Jones SM, Ballinger RE, and Nietfeldt JW. (1981) Herpetofauna of Mormon Island preserve, Hall County, Nebraska. The Prairie Naturalist 13(2): 33-41.

Jones JC and Dor B. (2004) Habitat associations of gopher tortoise burrows on industrial timberlands. Wildlife Society Bulletin 32(2): 456-464.

Kantrud HA, Krapu GL, and Swanson GA. (1989) Prairie basin wetlands of the Dakotas: a community profile. Biological Report No. 85, U.S. Fish and Wildlife Service, Washington, DC, 111 pp.

Karraker NE. (2001) String theory: reducing mortality of mammals in pitfall traps. Wildlife Society Bulletin 29: 1158-1162.

Kaul RB, Sutherland D, and Rolfsmeier S. (2012) The flora of Nebraska, Second Edition. Conservation and Survey Division, School of Natural Resources, University of Nebraska-Lincoln, Lincoln, NE, 967 pp.

Lane DR, Coffin CP, and Lauenroth WK. (2000) Changes in grassland canopy structure across a precipitation gradient. Journal of Vegetation Science 11(3): 359-368. 
Lichvar RW, Banks DL, Kirchner WN, and Melvin NC. (2016) The National Wetland Plant List: 2016 wetland ratings. Phytoneuron 2016-30: 1-17.

Lemmon EM, Lemmon AR, Collins JT, Lee-Yaw JA, and Cannatella DC. (2007) Phylogeny-based delimitation of species boundaries and contact zones in the trilling chorus frogs (Pseudacris). Molecular phylogenetics and evolution 44(3): 1068-1082.

Lynch JD. (1978) The distribution of leopard frogs (Rana blairi and Rana pipiens) (Amphibia, Anura, Ranidae) in Nebraska. Journal of Herpetology 12: 157-162.

Lynch JD. (1985). Annotated checklist of the amphibians and reptiles of Nebraska. Transactions of the Nebraska Academy of Sciences 13: 33-57.

McLean RP, Wright GD, and Geluso K. (2015) Cope's Gray Treefrog (Hyla chrysoscelis) along the Platte River, Hall County, Nebraska. Collinsorum 4(1): 2-4.

Mengak MT and Guynn Jr. DC. (1987) Pitfalls and snap traps for sampling small mammals and herpetofauna. The American Midland Naturalist 118(2): 284-288.

Meyer CK and Whiles MR. (2008) Macroinvertebrate communities in restored and natural Platte River slough wetlands. Journal of the North American Benthological Society 27: 626-639.

Mushet DM, Euliss Jr NH, and Stockwell CA. (2012) Mapping anuran habitat suitability to estimate effects of grassland and wetland conservation programs. Copeia 2012(2): 321-330.

Nippert JB, Ocheltree TW, Skibbe AM, Kangas LC, Ham JM, Arnold KBS, and Brunsell NA. (2011) Linking plant growth responses across topographic gradients in tallgrass prairie. Oecologia 166(4): 1131-1142.

[NWS DPI] New South Wales Department of Primary Industries. (2015) Determining soil texture using the ribboning technique. Primefact 1363, Department of Primary Industries, Agriculture New South Wales Water Unit, Orange, NSW, Australia, 3 pp.

Pauley NM, Harner MJ, Brinley Buckley EM, Burger PR, and Geluso K. (2018) Spatial analysis of borrow pits along the Platte River in south-central Nebraska, USA, in 1957 and 2016. Transactions of the Nebraska Academy of Sciences 38: 36-46.

Pittman SE, Jendrek AL, Price SJ, and Dorcas MR. (2008) Habitat Selection and Site Fidelity of Cope's Gray Treefrog (Hyla chrysoscelis) at the Aquatic-Terrestrial Ecotone. Journal of Herpetology 42(2): 378-385.

Platz JE and Lathrop A. (1993) Body size and age assessment and advertising male chorus frogs. Journal of Herpetology 27: 109-11.

Poague K. 2019. Important bird areas: Nebraska. National Audubon Society, New York, NY. Retrieved from the Internet 1 August 2020: https://www.audubon.org/ important-bird-areas/state/nebraska
R Core Team. (2015) R: A language and environment for statistical computing, version 3.2.1. R Foundation for Statistical Computing, Vienna, Austria. Retrieved from the Internet 1 September 2019: http:/ / www.R-project.org/

Reddy KR and Gale PM. (1994) Wetland processes and water quality: a symposium overview. Journal of Environmental Quality 23(5): 875-877.

Reed PB Jr. (1988) National list of Plant Species that Occur in Wetlands: National Summary. US Fish Wildlife Service Biological Report 88(24): 1-244

Rogers S. (2018) An Aerial Perspective: Using Unmanned Aerial Systems to Predict Presence of Lesser Earless Lizards (Holbrookia Maculata). Thesis, Fort Hayes State University, Fort Hayes, KS, 73 pp.

Schneider R, Stoner K, Steinauer G, Panella M, and Humpert M. (2011) The Nebraska Natural Legacy Project: State Wildlife Action Plan, Second Edition. The Nebraska Game and Parks Commission, Lincoln, NE, 352 pp.

Scott JL. (2005) Activity and habitat use of prairie skinks, Eumeces septentrionalis, in Manitoba. Thesis, University of Manitoba, Winnipeg, Manitoba, Canada.

Semlitsch RD and Bodie JR. (2003) Biological criteria for buffer zones around wetlands and riparian habitats for amphibians and reptiles. Conservation Biology 17(5): 1219-1228.

Shulse CD, Semlitsch RD, Trauth KM, and Williams AD. (2010) Influences of design and landscape placement parameters on amphibian abundance in constructed wetlands. Wetlands 30: 915-928.

Somma LA. (1987) Reproduction of the prairie skink, Eumeces septentrionalis, in Nebraska. Great Basin Naturalist 47(3): 373-374.

Smith BE and Keinath DA. (2007) Northern Leopard Frog (Rana pipiens): a technical conservation assessment. USDA Forest Service, Rocky Mountain Region, Lakewood, CO, 67 pp.

Symstad AJ, Wienk CL, and Thorstenson AD. (2008) Precision, repeatability, and efficiency of two canopy-cover estimate methods in northern Great Plains vegetation. Rangeland Ecology and Management 61: 419-429.

Todd BD, Winne CT, Willson JD, and Gibbons JW. (2007) Getting the drift: examining the effects of timing, trap type and taxon on herpetofaunal drift fence surveys. The American Midland Naturalist 158(2): 292-305.

Thormodsgard JM. (2009) Greater Platte River Basins - Science to Sustain Ecosystems and Communities. Fact Sheet 20093097, U.S. Geological Survey, Regional Science Office, Central Region, Denver, CO, 6 pp.

Tye SP, Geluso K, and Harner MJ. (2017) Geographic distribution: Hyla chrysoscelis (Cope's Gray Treefrog). Herpetological Review 48: 382-383.

Underhill JC. (1960) Breeding and Growth in Woodhouse's Toad. Herpetologica 16(4): 237-242. 
[USDA-NRCS] United States Department of AgricultureNatural Resources Conservation Service. (2016) USDA Plants Database. Retrieved from the Internet 1 August 2020: https://plants.sc.egov.usda.gov/java/

[USDA-NRCS] United States Department of AgricultureNatural Resources Conservation Service, Soil Survey Division. 2019. Web Soil Survey. Retrieved from the Internet 1 August 2020: http://websoilsurvey.nrcs.usda.gov/

[USFWS] United States Fish and Wildlife Service. (1978) Determination of critical habitat for the Whooping Crane. Title 50, Wildlife and Fisheries: Part 17, Endangered and Threatened wildlife and plants, Federal Register 43: 20938-20942.

VanDerwalker JG. (1982) The Platte River Whooping Crane Critical Habitat Maintenance Trust.

In J.C. Lewis (Editor), Proceedings of the 1981 Crane Workshop, pp. 4-6 (Tavernier, FL: National Audubon Society).

Vittinghoff E and McCulloch CE. (2007) Relaxing the rule of ten events per variable in logistic and Cox regression. American Journal of Epidemiology 165: 710-718.
Whiles MR and Goldowitz BS. (2005) Macroinvertebrate communities in Central Platte River wetlands: patterns across a hydrologic gradient. Wetlands 25: 462-472.

Wilson JD and Gibbons JW. (2010) Drift fences, coverboards, and other traps. In C.K. Dodd Jr. (Editor), Amphibian Ecology and Conservation: A Handbook of Techniques, pp. 229245. (Oxford, United Kingdom: Oxford University Press).

Wells KD. (2010) The ecology and behavior of amphibians. (Chicago, Illinois: University of Chicago Press).

Welsh Jr. HH and Lind AJ. (1995) Habitat correlates of the Del Norte salamander, Plethodon elongatus (Caudata: Plethodontidae) in northwestern California. Journal of Herpetology 29: 198-210.

White GC and Burnham KP. (1999) Program MARK: survival estimation from populations of marked animals. Bird Study 46: S120-S139.

Williams GP. (1978) The case of the shrinking channels: the North Platte and Platte Rivers in Nebraska. Geological Survey Circular 781, U.S. Geological Survey, Arlington, VA 48 pp.

Appendix 1. Metadata for sites surveyed from 5 June to 30 July 2019 within the Central Platte River Valley, including: system type as terrestrial (TR) or aquatic (AQ), Latitude (Lat.) and Longitude (Lon.), starting (St.) and ending (End) trap dates, total nights trapped (NTs; accounts for days traps were closed due to moisture), trap types deployed at each site including pitfall (PF), funnel (FN), hoop (HP), box (BX), and cover board (CB), as well as total traps (TTL TRPs), total trap nights (TTL TRP NTs; total nights*total traps), total captures of all species (TTL CPs), total captures per trap night all species (CPs/NT).

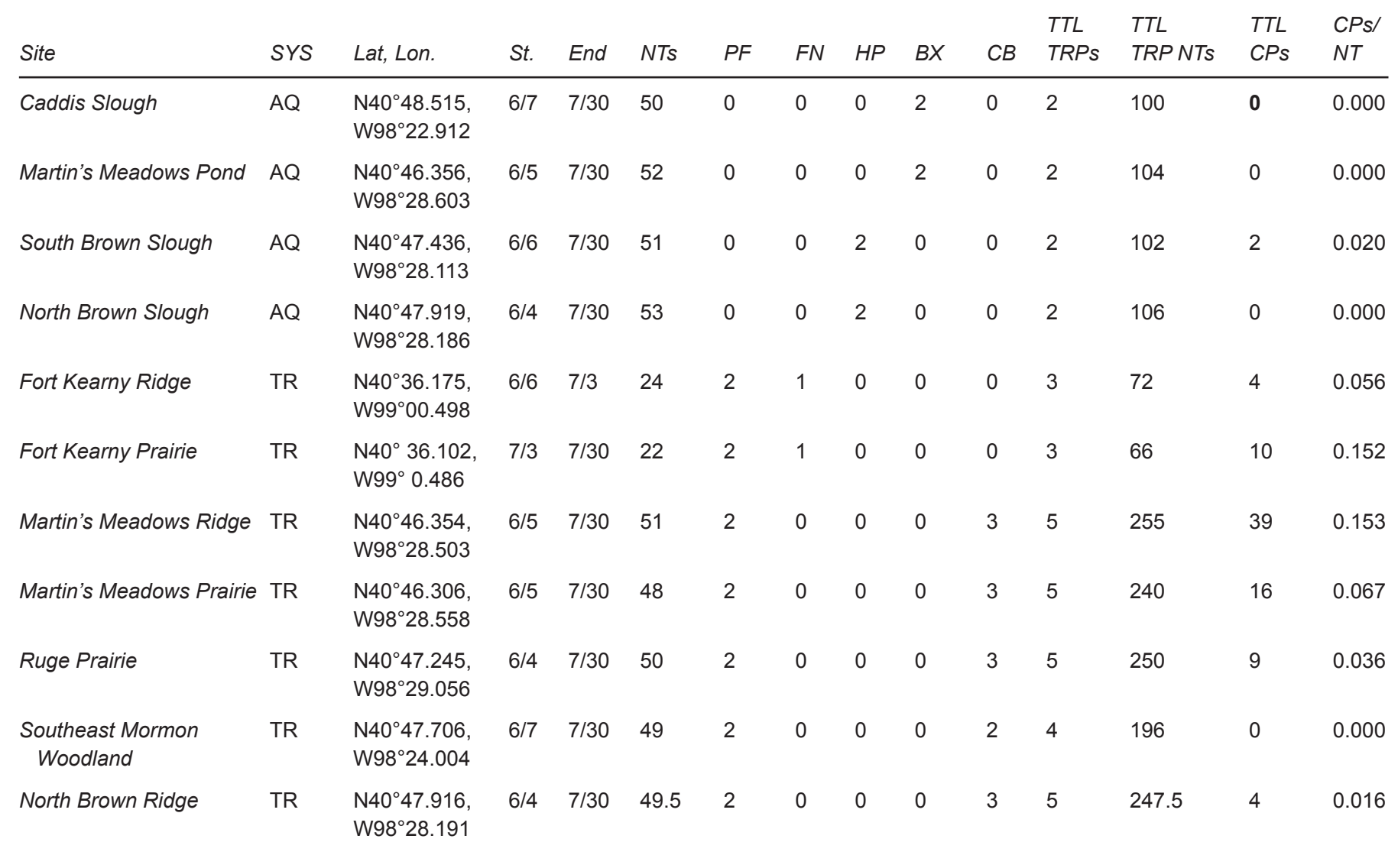

